\title{
Research on the Applied Talents Training of Radio and Television Directing Major Under the Employment Orientation QU Qinghong ${ }^{\mathrm{a}}$, JIANG Chunxu ${ }^{\mathrm{b}}, \mathrm{GAO}$ Feng $^{\mathrm{c}}$

\author{
Baicheng Normal University, Baicheng 137000, China
} \\ aemail: quqinghong@163.com, bemail: 115721119@qq.com, cemail: gaof317@163.com
}

\section{Keywords: Employment Orientation, Radio and Television Directing Major, Applied Talents}

\begin{abstract}
With the continuous development of new media technology, the market demand for employment increases gradually, but market competition also becomes increasingly fierce. The development of radio and television major in China, need more talents of radio and television major, and skill and quality requirements for talents are also increased. The rapid development of new media, the demand for applied talents of radio and television director major is increasing gradually. Under the employment orientation, this article will analyze and study the training of applied talents of radio and television director major, and put forward some corresponding measures.
\end{abstract}

\section{Introduction}

With the coming of new media era, the development of radio and television directing major must keep up with the trend of the times and need continue to carry out reform, the talents training of radio and television directing major should be carried out under the employment oriented. The Chinese government attaches great importance to the work of publicity for the media, radio and television directing major also received wide attention. In recent years, the Ministry of education attaches great importance to the development of radio and television directing major, which should gradually adapt to the needs of the market and be effectively combined with the employment of students. In the background of the development of the era of big data, the requirements for personnel is also rising, and in the era of big data people can not leave the data, but the data is too messy, so it is also very important fetch how to extract effective information from a large amount of data. With the radio and television directing major as a popular one, it will face great challenge, so the teachers of television major should be fully aware of the importance of reform and change the traditional model of talent training to cultivate talents for social development [1].

\section{Characteristics of Radio and Television Directing Major}

Since the twentieth Century, the major colleges and universities in China have set up radio and television director professional to cultivate a large number of radio and television director talents for the media industry and a number of publicity departments. The continuous development of information technology has a great impact on the radio and television director major, and there are also some problems in the talent training of radio and television director major. There are also some loopholes in some theoretical knowledge, and the training mode of radio and television director major has been unable to meet the current market demand, so colleges and universities should pay great importance to the training of radio and television director major, and should continue to explore ways and means to improve the quality of talent training. The characteristics of radio and television director major are mainly reflected in its strong practicality, and its theory should be organically combined with practice, so students should not only master the basic theoretical knowledge, but also have skilled operation ability. For example, mastering the operation of a simple camera and meanwhile having some innovative ability, which is a combination of mental and physical work. At present, with the continuous development of social economy, the application of new media technology is very extensive, the making of some micro film work also requires professional team as a support, the need for professional shooting team and later production team. Therefore, the talent training of radio and television directing major must be adapted to the current 
social development trend, formulate the goal and direction of talent training, and dock with the industry. The demand of radio and television directing major for talent is relatively high, who needs to have deep thinking and skilled professional skills and be to be able to solve the problems encountered in practical work [2].

\section{Current Situation of Radio and Television Directing Major}

With the current economic and social development, China's media industry has the rapid development, whose talent demand for radio and television major is becoming more and more high, so major colleges and universities have set up the radio and television professional and meanwhile expand the scale of enrollment in order to better meet the needs of the community. But there still exist many problems, firstly, the major colleges and universities expand enrollment, but the professional goal setting is not adjusted, resulting in talent cultivation not to adapt to the current needs of the society, and students learn some knowledge cannot be better applied to practice; Secondly, teaching facilities of some colleges and universities are relatively backward, moreover, the new media technology is continuously developing and new things and technologies will continue to emerge, the teaching can not adapt to a current development trend, some facilities are relatively backward, so the students in the learning process lack the learning and contact for advanced equipment, which results in knowledge learned in the school not to be used to practice. television directing major has high practical requirement that require the students to fully grasp the use of the instrument adequately; Thirdly, some colleges and universities expand the enrollment blindly, and the radio and television directing major media industry as an emerging professional will be subject to public attention, if blindly expanding enrollment will result in oversupply, the students after graduation can not better adapt to social development and lead to being eliminated in the fierce social competition; Finally, although some universities opened a television professional, but the teachers strength is not enough, their teaching idea is relatively old and a teaching mode still retain the original standards, not with the development of the society [3].

\section{Problems Existing in the Talent Training of Radio and Television Directing Major in the New Media Era}

With the rapid development of new media technology, the application of network technology and digital technology is widely used, , especially information technology are made full use in all walks of life, for example education. Information technology is also gradually applied to the radio and television directing major, whose demand for the new technology is relatively high. The development of the new media technology gradually broke some traditional technology and methods, whose communication channels and methods are also diverse. The media for the director of professional talent requirements are also getting higher and higher, so employment oriented applied talents training is also the focus of the current college education. First of all, technology requirements of the radio and television directing major are relatively high in universities, but some students' study is impetuous, most of who is art candidates with relatively poor cultural foundation, although these students have very strong creativity, lack of professional theoretical knowledge to master, at the same time most students of the radio and television directing major pay too much attention to technical operation and neglect the knowledge of the theory.

Secondly, students' theoretical knowledge can not be combined with practice, and moreover, the radio and television directing major stronger pay attention to practice and the practical application of theoretical knowledge, whose related facilities and equipment are required to have strong applicability, in order to cultivate the high-quality TV applied talents. The educational background of applied teachers in colleges and universities is generally relatively low, and the teaching of students' theoretical knowledge is neglected in the process of teaching, which leads to the lack of students' theoretical knowledge. Thirdly, the radio and television directing major in colleges did not break the traditional teaching mode, and still used a traditional teaching method in the teaching process of the theory and practice, not considering the change of the teaching contents 
and teaching methods, and the teaching process was more rigid and inflexible which often limited the students' thinking and creativity, this kind of passive learning had limited the students' learning enthusiasm and was not conducive to the establishment of the subject position of students, leading students' learning enthusiasm not high. Finally, some teachers' thought in colleges of the radio and television directing major was the more traditional and used the traditional teaching mode, which can not adapt to the current social development needs. teachers for television professional teaching methods are too traditional, so that students trained with this way can not well adapt to the current needs of professional, and in the teaching process there will exist a kind of irregular, non blind phenomenon of teaching system. With the coming of new media era, students trained in the radio and television directing major should have the traditional media technology, digital multimedia technology and others, but many radio and television directing majors are not fully aware of the rapid development of new media technology and do not have a forward-looking in the talent positioning [4].

\section{Cultivation of Talent Quality of the Radio and Television Directing Major under Employment Orientation}

The radio and television directing major has stronger strong application and practicality, some colleges pay more attention to the cultivation of students' practical ability and the students "editing" and "directing" training, and focus on early work focused on radio and television directing, including the creative planning and editorial writing of radio and television programs, that shows the basic requirements for talents in radio and television directing major is that students must have actual operation ability, the artistic accomplishment of construction of image story and comprehensive cultural literacy. With the development of the new media technology, talent training of the radio and television directing major should meet the needs of the development of new media and be in line with the needs of the times.

Ability to Analyze Information. The development of new media era, with the advent of the era of big data, how to find useful information resources from a large amount of data, how to select information processing is critical. Radio and television professional to train students to be able to select some useful information from a large amount of information, select some useful information from a large amount of data in the data, and the ability of processing of large amounts of data. With the development of new media era and the advent of the era of big data, it is critical how to find useful information resources from a large amount of data and how to select information processing. The radio and television directing major should train students' ability to select some useful information from a large number of information resources, select some useful information from a large amount of data and process a large amounts of data. In the era of big data with information developed, people pay attention to use computer technology to find a large number of useful data from large data files, in a series of data processing, students need to quickly find news stories needed by the public. The open data platform has changed the life of the public and the way of news communication and production. In universities, the radio and television directing major should cultivate the ability to analyze and understand the relevant information in public opinion. The emergence of a large number of information in social media has caused a certain threat to the traditional mainstream media and will also have a great impact on society. The radio and television directing personnel need to have the ability to plan and guide public opinion on relevant programs, and find new data and information from social media [5].

Cultivating Students' ability to Construct Stories. Radio and television professional pay attention to the cultivation of narration of the story of students, the basic structure of the story narrative is also described in the TV program. The emergence of big data has changed the traditional way of radio and television, the related data analysis personnel should have received some valuable information from a large amount of data, and through sorting and screening the relevant information, to complete the narrative. Often intuitive data analysis more close to people's life, the way of construction compared to interview work more intuitive and reliable [6]. 


\section{Training Measures for Professional Talents of Radio and Television Directing under Employment Orientation}

In the social trend of the rapid development of new media, also constantly changing culture some college radio and television professional talent, but also encounter ideas, some external factors such as environmental impact. Only to strengthen the research on the training mode of talents, can for the training of personnel to provide a broader space.

The Teaching Materials of Radio and Television Directing should Conform to the Social Development. In the radio and Television University director of professional teaching, the first teaching material is the most important. The radio and television professional teaching materials is the basis of a trend of the social development with only the teaching material content, can be used as a basis for teaching reference, in the professional course teaching, textbook is the important content of teaching authority. The content of construction is also in the professional teaching. Therefore, teachers should pay attention to the accumulation of experience in the teaching process, to give students some famous colleges in the theoretical knowledge, textbook content must pay more attention to some new contents of news communication and new media development, should pay attention to the practical knowledge, broaden the students should pay attention to the field of vision, cultivate students' innovative thinking and ability [7].

The Teaching Content should be Organically Integrated with the New Media. In the current development of new media era, media forms of diversification, diversification of channels of information dissemination, the popularization of network technology has put forward higher requirements for radio and television professional students, students in the social position, must be able to fully grasp the various forms of media. Therefore, the director of professional radio and television to be able to recognize a trend in the development of new media, to realize the development of the new media of radio and television professional impact and influence, to constantly adjust the content of the course, the director of professional radio and television and the Internet, some new media digital broadcasting standards. For example, in the process of teaching, teachers should pay attention to the students "the design and production of network news and some practice teaching contents better teaching, so that students can understand the current situation of the development of new media in the constant practice, to learn Make some new media content with audio and video.

Enhance the Participation of Teachers and Students in Various Media Competitions. The rapid development of social information technology, the enormous pressure on employment and social competition between universities. Radio and television professional students' employment pressure is relatively large. How students can better show their professional strength, we need to show through the game show the strength of the students, the cooperation between teachers and students and creative enthusiasm fully transfer. For example, teachers and students to actively participate in various universities in the games, to keep learning new knowledge and skills, learn some teaching methods and skills for some new, award-winning teachers and students in reward, fully arouse students' enthusiasm and creativity, but also conducive to improve the visibility of the school and professional.

\section{Conclusion}

In summary, the current employment guidance, radio and television professional teaching should adapt to the trend of social development, to be able to fully adapt to the development trend of new media, should pay attention to the organic combination between theory and practice knowledge. To innovate teaching mode of radio and television professionals in course teaching, to update the knowledge structure, to make up for some deficiencies exist in the teaching, to cultivate a group of professional talents. 


\section{Acknowledgements}

In this paper, the research was sponsored by the Educational Science Project of Jilin province during “13th Five-Year Plan” in 2017 (No. GH170595).

\section{References}

[1] JI Zhe. Discussion on the construction strategy of radio and TV University director of professional application of new media perspective[J]. Modern Communication,2014,6

[2] XING Limei. Research on diversified applied talents training mode of radio and television directing major in the era of big data[J]. Journal of Changzhou Institute of Technology(Social Science Edition), 2014,32

[3] ZHANG WanTing. Research on studio teaching mode of radio and television directing major in local application oriented Universities[J]. Research and Practice on Higher Education,2014,33

[4] YANG Huilin, ZHAO Qinfen. Study on the training path under the local radio and television university professional applied talents of all media-Taking Honghe University radio and television specialty for example[J]. News Research,2015,04

[5] WANG Lili. Study on the training mode of Applied Talents in the new era radio and television media[J]. Ability and Wisdom,2014,18

[6] LI Wei. The research paradigm of training applied university radio and television director in the context of the integration of media professionals[J]. Guangxi Journal of Light Industry, 2015,35

[7] WANG Lijun, YUAN Lin. Talent training and industrial docking mode of applied radio and TV Directing specialty[J]. Modern SOE Research,2016,12 